\title{
Seed rain in areas with and without bamboo dominance within an urban fragment of the Atlantic Forest
}

\author{
Maria Tereza Grombone-Guaratini ${ }^{1,5}$, Luciana Ferreira Alves ${ }^{2}$, Daniella Vinha ${ }^{3}$ and Geraldo Antônio Daher Corrêa Franco ${ }^{4}$
}

Submitted: 22 November, 2012. Accepted: 19 November, 2013

\begin{abstract}
Understanding the flow of diaspores is fundamental for determining plant population dynamics in a particular habitat, and a lack of seeds is a limiting factor in forest regeneration, especially in isolated forest fragments. Bamboo dominance affects forest structure and dynamics by suppressing or delaying the recruitment of and colonization by tree species as well as by inhibiting the survival and growth of adult trees. The goal of the present study was to determine whether dominance of the bamboo species Aulonemia aristulata (Döll) McClure in the forest understory influences species abundance and composition. We examined the seed rain at two noncontiguous sites ( $1.5 \mathrm{~km}$ apart) within an urban forest fragment, with and without bamboo dominance $\left(\mathrm{BD}+\right.$ and $\mathrm{BD}-$ areas, respectively). Sixty seed traps $\left(0.5 \mathrm{~m}^{2}\right.$, with a $1-\mathrm{mm}$ mesh) were set in the $\mathrm{BD}+$ and $\mathrm{BD}$ - areas, and the seed rain was sampled from January to December 2007. Diaspores were classified according to dispersal syndrome, growth form and functional type of the species to which they belonged. There were significant differences between the two areas in terms of seed density, species diversity and dispersal syndrome. The $\mathrm{BD}+$ area showed greater seed density and species diversity. In both areas, seed distribution was limited primarily by impaired dispersal. Bamboo dominance and low tree density resulted in fewer propagules in the seed rain. Our results suggest that low availability of seeds in the rain does not promote the maintenance of a degraded state, characterized by the presence of bamboo.
\end{abstract}

Key words: Aulonemia aristulata, dispersal, human activity, natural regeneration

\section{Introduction}

Landscape fragmentation and the loss of habitat are widespread processes in the modern world and represent one of the most import threats to global biodiversity (Laurance et al. 2001). Among the causes of deforestation, the expansion of urban areas in the last 50 years requires special consideration (Chant 2010). Recent studies have identified the effects of landscape fragmentation on several natural processes, including changes in seed flow due to an overall reduction in dispersal agents (Melo et al. 2006). Within this context, knowledge on the dynamics of urban forests, where the effects of human disturbance have a greater impact, could provide information on how to manage such forest fragments (Burley et al. 2008).

Seed rain is one of the initial phases of forest regeneration (Holl 1999) and is one of the fundamental steps for determining the potential population that will recolonize a given area (Harper 1977). In fragmented landscapes, the seed rain is strongly influenced by forest connectivity (Pivello et al. 2006). In contrast to continuous forests, post-disturbance regeneration in isolated forest fragments is dependent on allochthonous sources of diaspores and dispersers (Burley et al. 2008). According to Burley and contributors, dependence on allochthonous sources is exacerbated in urban fragments isolated from potential seed sources, resulting in the establishment of non-native species and the dominance of individual native species that are potentially favored by natural disturbances (2008).

Woody bamboos are perennial grasses, widely distributed in temperate, subtropical and tropical forests (Södertröm \& Calderon 1979, Judziewicz et al. 1999), that display a wide ecological range in response to canopy disturbances. Bamboos may become dominant species in the understory and gap openings (González et al. 2002). Some species of bamboo are dependent on major disturbances for recruitment of new individuals and subsequent levels of population persistence, growing more vigorously and producing more biomass in open areas than under the

\footnotetext{
${ }^{1}$ Instituto de Botânica de São Paulo, Núcleo de Ecologia, São Paulo, SP, Brazil

${ }^{2}$ Instituto Agronômico de Campinas, Centro de Pesquisa e Desenvolvimento de Recursos Genéticos Vegetais, Campinas, SP, Brazil

${ }^{3}$ Universidade Estadual de Campinas, Pós-Graduação em Biologia Vegetal, Campinas, SP, Brazil

${ }^{4}$ Instituto Florestal de São Paulo, Divisão de Dasonomia, São Paulo, SP, Brazil

${ }^{5}$ Author for correspondence: mgromboneguaratini@gmail.com
} 
forest canopy (Narukawa \& Yamamoto 2002). Other species may be understory, shade-tolerant species (Widmer 1998) or are able to persist within that habitat due to the periodic occurrence of minor or intermediate disturbances (Griscom \& Ashton 2003).

After any type of natural or human disturbance some patches of tropical forests can become dominated by bamboos. This process has an impact on forest structure and dynamics by suppressing or delaying the recruitment of and colonization by tree species, as well as affecting the survival and growth of individual adult plants (Griscom \& Ashton 2003; 2006; Guilherme et al. 2004; Doležal et al. 2009, Vinha et al. 2011). Bamboo dominance has been associated with the competitive efficiency of bamboos, which is attributed to the intense production of biomass over many decades, exclusively by vegetative propagation (Janzen 1976, Guilherme et al. 2004, Griscon \& Ashton 2006) and to the fact that bamboo plants can release allelopathic compounds (Grombone-Guaratini et al. 2009). Bamboo dominance can also persist due a decrease in the number of diaspores in the seed rain (Abe et al. 2002, Holz \& Veblen 2006). In general terms, a lack of seeds for colonization could be due to a limited number of seeds (source limitation) or a limited number of diaspores (dispersal limitation) (Muller-Landau et al. 2002).

The Parque Estadual das Fontes do Ipiranga (PEFI, Fontes do Ipiranga State Park, ca. 530 ha) comprises an isolated urban fragment of dense rain forest within the Atlantic Forest Biome (Veloso et al. 1991). The PEFI is located in São Paulo city, state of São Paulo, Brazil, and is part of the São Paulo Green Belt Biosphere (UNESCO). At PEFI, past disturbances, such as selective logging, fire, clearings, and atmospheric pollution, have resulted in discontinuity of tree layers and canopy (Pivello \& Peccinini 2002). It is this situation that has most likely promoted the occupation and dominance of the understory by Aulonemia aristulata (Döll) McClure, a rhizomatous, scandent Bambusoideae species endemic to the semideciduous and moist forests of the southeastern and central regions of Brazil. In this study, we test the hypothesis that dominance by $A$. aristulata prevents the arrival of seeds and reduces their availability for subsequent regeneration across the area in question. Our expectation was that the combination of bamboo dominance and low tree density would reduce the density and richness of the seed rain, thus favoring the maintenance of a degraded forest state.

\section{Material and methods}

\section{Study area}

The study was carried out at the PEFI, located in the city of São Paulo (233' $40^{\prime \prime}$ S, $46^{\circ} 36^{\prime} 38^{\prime \prime}$ W; $770-825$ m. a.s.l.), southeastern Brazil. The regional climate is tropical temperate with a rainy summer and dry winter, classified as Cwb type according to Köppen's classification system. Annual precipitation averages $1544 \mathrm{~mm}$, but between April and September, mensal rainfall is less than $100 \mathrm{~mm}$. Average minimum and maximum monthly temperatures are $16.7^{\circ} \mathrm{C}$ in July and $22.4^{\circ} \mathrm{C}$ in February. Latosols (non-aquic oxisols) are the predominate soil type in the PEFI. Approximately 350 hectares of PEFI are covered by tropical secondary forest (lower montane rain forest sensu Oliveira-Filho \& Fontes 2000). Previous floristic studies recorded approximately 380 different tree species in the PEFI, including a predominance of typical Atlantic Forest families (Barros et al. 2002). Although Myrtaceae, Fabaceae, Lauraceae and Melastomataceae are the most abundant families, pioneer tree species such as Alchornea sidifolia Müll.Arg. and Cecropia glaziovii Snethl are commonly found in open areas and are characteristic of secondary-growth forest patches in terms of successional status. Almost 4 ha of the PEFI's understory are covered by Aulonemia aristulata. This native bamboo species is perennial, with pachymorph rhizomes and woody stems that can be erect or arched (for more details, see Grombone-Guaratini et al. 2011). Under natural conditions, the distribution of A. aristulata is sparse throughout the understory. However, in more disturbed environments, there is a high densities of bamboo, which may be the dominant species.

\section{Seed rain data collection}

To assess the effects that bamboo has on the arrival and distribution of seeds throughout the forest, we evaluated two, non-contiguous, 0.7 ha sampling areas: a bamboodominated area (BD+ area) and an area without bamboo dominance $(\mathrm{BD}-$ area). The $\mathrm{BD}+$ area was clearly disturbed, exhibiting a low density of trees, an open canopy and a predominance of $A$. aristulata, which occupied approximately $60 \%$ of the understory and were $\leq 4 \mathrm{~m}$ in height. The $\mathrm{BD}-$ area, located at least $1.5 \mathrm{~km}$ from the $\mathrm{BD}+$ area, had a closed canopy and a high density of tree species. The total density of tree species with a diameter at breast height $\geq 4.8 \mathrm{~cm}$ was 1767 individuals $\mathrm{ha}^{-1}$ in the $\mathrm{BD}$ - area and 1354 individuals $\mathrm{ha}^{-1}$ in the $\mathrm{BD}+$ area. According to Vinha et al. (2011), who evaluated the same two sites, the mean percent canopy opening also differed significantly between the $\mathrm{BD}+$ and $\mathrm{BD}-$ areas $(12.05 \pm 0.42 \%$ vs. $8.10 \pm$ $0.36 \%)$, as did diffuse incident radiation $(21.96 \pm 0.66 \%$ vs. $11.65 \pm 0.51 \%)$. Those authors suggested that the observed differences between the $\mathrm{BD}+$ and $\mathrm{BD}$ - areas in terms of the density of tree species $>20 \mathrm{~m}$ in height (43 individuals $\mathrm{ha}^{-1}$ vs. 123 individuals ha ${ }^{-1}$ ) was attributable to the greater proportional opening of the canopy.

Within each of the study areas, we established a 0.7 -ha sample plot, subdivided into $70(10 \times 10 \mathrm{~m})$ individual subplots. To analyze the seed rain, we set up 30 circular $0.5-\mathrm{m}^{2}$ seed traps, each with a fine $(1.0-\mathrm{mm})$ nylon mesh, suspended $50 \mathrm{~cm}$ above the ground and randomly distributed 
within each plot. Seed rain was measured from January to December 2007. Traps were emptied monthly and the collected material was dried and sorted to identify the apparently viable diaspores (Foster 1985). Diaspores were defined as all fruit and seeds that constituted dispersal units (van der Pijl 1982). We analyzed all apparently viable diaspores with a diameter $>1 \mathrm{~mm}$. The diaspores were counted and classified into morphospecies; each species was then identified through comparison with materials available at the Maria Eneida Kauffman Fidalgo Herbarium of the Botanical Institute of São Paulo (SP), as well as through verification by specialists and comparison with specific literature, particularly the Phanerogamic Flora of the Fontes do Ipiranga State Park (Wanderley et al. 2002), Carvalho (1994), Lorenzi (1992; 1998), Rossi (1994), Gandolfi et al. (1995). The nomenclature for the families followed APG II (2003). After identification, species were classified according to growth form (tree, shrub, herbaceous and lianas), successional class (pioneer or non-pioneer, sensu Swaine \& Whitmore 1988) and dispersion mode (anemochory, autochory or zoochory), according to van der Pijl (1982).

\section{Data analysis}

The difference in total annual density of dispersed diaspores (diaspores $\mathrm{m}^{-2}$ ) between areas was compared using t-tests followed by log transformation of the data. The Shapiro-Wilk test was used to test for data normality and Levene's test was used to assessing homogeneity of variances (Zar 1999). Calculations were made using the PAST program (Hammer et al. 2001). The distribution of species in the samples was assessed by calculating the density of diaspores and measuring absolute and relative frequencies (Müeller-Dombois \& Ellenberg 1974). The chi-square test $\left(\chi^{2}\right)$ was used to identify differences in functional groups between areas, with a null hypothesis that areas do not differ in terms of diaspore abundance by growth form category (tree-shrub vs. lianas), succession class (pioneers vs. non-pioneers) or dispersal mode (biotic vs. abiotic). Lianas were not taken into consideration as part of the succession class comparisons because of a lack of classification information for that particular species group.

The floristic similarity between areas was assessed using the Sørensen index. The Multiple Response Permutation Procedure (MRPP) was used to verify the null hypothesis that no differences exist in relation to seed rain floristic composition between areas, based on the Sørensen similarity index at a significance level of $5 \%$, utilizing the program PC-ORD, version 6.0 (McCune \& Mefford 2011). The predicted mean levels of species richness and diversity were calculated based on the total number of species $(n=54)$.

For the comparisons of species richness and diversity, a rarefaction procedure was used to avoid possible underestimates (Gotelli \& Colwell 2001). Replacements of 1000,
3000 and 5000 individuals were made after an initial 9999 repetitions, taking into account the pre-determined number of diaspores obtained. Diversity was quantified using the Shannon-Wiener diversity index ( $\left.\mathrm{H}^{\prime}\right)$. Estimates were then compared by evaluating the $95 \%$ confidence intervals, which indicate an absence of any differences when overlapping. Calculations were made using the EcoSim program, version 7.0 (Gotelli \& Entsminger 2001).

Seed limitation, defined as the proportion of seed traps that did not receive any seeds (Muller-Landau et al. 2002), was calculated for the nine most abundant and common species in the two study areas ( $80 \%$ of the diaspore total in the $\mathrm{BD}+$ area, compared with $91 \%$ in the $\mathrm{BD}-$ area) using the following formula:

$$
\text { Seed limitation }=1-a / n
$$

where $a$ is the number of seed traps in which the diaspores were collected, and $n$ is the total number of seed traps.

The stochastic method developed by Clark et al. (1998) was used to calculate the limitation of seed sources, taking into account the quantity of seed traps available and whether the seeds were distributed in a uniform manner. The proportion of seed traps that were not likely to receive seeds were calculated using the following equation, with the Poisson probability of no event occurring (i.e., the probability that no seeds of a specific species would be received) given an expected seed limitation:

$$
\text { Source limitation }=\exp (-s / n)
$$

where $s$ is the total number of seeds collected and $n$ is the total number of seed traps.

To compare the proportion of seed traps that received seeds in relation to the proportion of seed traps capable of receiving seeds, in the event that distribution was uniform, the dispersal limitation was calculated using the following formula:

$$
\text { Dispersal limitation }=1-[(a / n) /(1-\text { source limitation })]
$$

Seeds were considered to be limited if the calculated indices were $>0.60$.

\section{Results}

\section{Density}

Over the one-year study period, a total of 15,543 diaspores were collected from the two sampled areas. The density of dispersed diaspores was greater in the $\mathrm{BD}+$ area than in the BD- area (638.73 vs. 397.47 diaspores $\mathrm{m}^{-2}$ ), a difference that was statistically significant $(t=4.27, \mathrm{p}<0.001)$. 


\section{Floristic composition, species richness and diversity}

In one year of seed rain collection, we identified a total of 54 morphospecies, representing 38 genera and 25 families (Tab. 1). Asteraceae was the most important family across both areas, which were statistically equivalent in terms of the abundance of diaspores $(77 \%$ in the $\mathrm{BD}+$ area; $87.6 \%$ in the $\mathrm{BD}-$ area) and species richness $(13.5 \%$ in the $\mathrm{BD}+$ area; $23.2 \%$ in the $\mathrm{BD}-$ area). Asteraceae, Myrsinaceae, Euphorbiaceae, Sapindaceae, Rubiaceae and Urticaceae collectively accounted for $95.8 \%$ of all dispersed diaspores in the $\mathrm{BD}+$ area, whereas Asteraceae, Sapindaceae, Rosaceae and Boraginaceae collectively accounted for $95.8 \%$ in the BD- area. The diaspores most frequently found in the seed traps in the $\mathrm{BD}+$ area were from the species Mikania cordifolia, Asteraceae sp. 1 and Piptocarpha oblonga, while only Asteraceae sp. 1 and $M$. cordifolia were frequently recovered in the $\mathrm{BD}-$ area. Nevertheless, the relative contribution of species was different in each area. Asteraceae sp. 1, M. cordifolia and P. oblonga accounted for $74.3 \%$ of all diaspores collected in the BD+ area, whereas $V$. diffusa accounted for $70.7 \%$ of all diaspores collected in the BD- area. These species had the highest absolute densities in each of the studied areas (Tab. 1). Of the species identified in the $\mathrm{BD}+$ area, $67.6 \%$ contributed fewer than 10 diasporesm ${ }^{-2}$ compared with $83.3 \%$ of those identified in the $\mathrm{BD}-$ area. Unique species accounted for $29.6 \%$ of all species in the BDarea and $20.4 \%$ in the $\mathrm{BD}+$ area. The floristic similarity between the two areas was 0.68 for all of the species identified. The MRPP test revealed that the floristic composition of the seed rain differed significantly between the two areas $(A=0.09 ; \mathrm{p}<0.001)$. The estimated richness of species was greater in the $\mathrm{BD}-$ area at the highest resampling level only (5000). However, species diversity was greater in the $\mathrm{BD}+$ area for all diversity estimates (resamplings of 1000, 3000 and 5000; Fig. 1).

Table 1. List of species per family and their respective functional groups along with the absolute number, density and frequency of diaspores collected in the seed rain for the areas with and without bamboo dominance in the Fontes do Ipiranga State Park, São Paulo, Brazil, from January to December 2007.

\begin{tabular}{|c|c|c|c|c|c|c|c|c|c|}
\hline \multirow{2}{*}{$\begin{array}{l}\text { FAMILY } \\
\text { Species* }\end{array}$} & \multirow[t]{2}{*}{ Habit } & \multirow[t]{2}{*}{$\mathrm{SC}$} & \multirow[t]{2}{*}{$\mathrm{DM}$} & \multicolumn{2}{|c|}{$\begin{array}{c}\text { Number of } \\
\text { seeds }\end{array}$} & \multicolumn{2}{|c|}{$\begin{array}{l}\text { Absolute } \\
\text { density }\end{array}$} & \multicolumn{2}{|c|}{$\begin{array}{l}\text { Absolute } \\
\text { frequency }\end{array}$} \\
\hline & & & & $\mathrm{BD}+$ & $\mathrm{BD}-$ & $\mathrm{BD}+$ & $\mathrm{BD}-$ & $\mathrm{BD}+$ & $\mathrm{BD}-$ \\
\hline \multicolumn{10}{|l|}{ AMARANTHACEAE } \\
\hline Hebanthe paniculata Mart. & SCAN & - & ANE & 72 & - & 9.60 & - & 0.17 & - \\
\hline \multicolumn{10}{|l|}{ ANNONACEAE } \\
\hline Xylopia brasiliensis Spreng. & TREE & NP & $\mathrm{ZOO}$ & 32 & 53 & 4.27 & 7.07 & 0.37 & 0.27 \\
\hline \multicolumn{10}{|l|}{ APOCYNACEAE } \\
\hline Aspidosperma olivaceum Müll.Arg. & TREE & NP & ANE & - & 7 & - & 0.93 & - & 0.07 \\
\hline Aspidosperma sp. & TREE & NP & ANE & 9 & 3 & 1.20 & 0.40 & 0.07 & 0.03 \\
\hline Peltastes sp. & SCAN & - & ANE & 17 & 4 & 2.27 & 0.53 & 0.20 & 0.13 \\
\hline \multicolumn{10}{|l|}{ AQUIFOLIACEAE } \\
\hline Ilex sp. & TREE & $\mathrm{P}$ & $\mathrm{ZOO}$ & - & 1 & - & 0.13 & - & 0.03 \\
\hline \multicolumn{10}{|l|}{ ARECACEAE } \\
\hline Syagrus romanzoffiana (Cham.) Glassman & TREE & $\mathrm{P}$ & $\mathrm{ZOO}$ & 4 & - & 0.53 & - & 0.10 & - \\
\hline \multicolumn{10}{|l|}{ ASTERACEAE } \\
\hline Asteraceae sp. 1 & - & - & ANE & 2461 & 657 & 328.13 & 87.6 & 0.87 & 0.87 \\
\hline Asteraceae sp. 2 & - & - & ANE & - & 3 & - & 0.40 & - & 0.10 \\
\hline Asteraceae sp. 3 & - & - & ANE & - & 14 & - & 1.87 & - & 0.27 \\
\hline Eupatorium sp. 1 & - & $\mathrm{P}$ & ANE & - & 9 & - & 1.20 & - & 0.17 \\
\hline Eupatorium sp. 2 & - & $\mathrm{P}$ & ANE & - & 10 & - & 1.33 & - & 0.13 \\
\hline Mikania cordifolia (L.F.) Willd. & SCAN & - & ANE & 3047 & 283 & 406.27 & 37.73 & 0.87 & 0.27 \\
\hline Mikania sp. 2 & SCAN & - & ANE & - & 4 & - & 0.53 & - & 0.10 \\
\hline Piptocarpha oblonga (Gardn.) Baker & SCAN & $\mathrm{P}$ & ANE & 1611 & 30 & 214.80 & 0.40 & 0.40 & 0.10 \\
\hline Piptocarpha macropoda (DC.) Baker & TREE & $\mathrm{P}$ & ANE & 1 & 1 & 0.13 & 0.13 & 0.03 & 0.03 \\
\hline Vernonia diffusa Less. & TREE & $\mathrm{P}$ & ANE & 259 & 4214 & 34.53 & 561.87 & 0.40 & 0.87 \\
\hline \multicolumn{10}{|l|}{ BIGNONIACEAE } \\
\hline Pithecoctenium echinatum (Jacq.) Baill. & SCAN & - & ANE & 1 & 2 & 0.13 & 0.27 & 0.03 & 0.03 \\
\hline
\end{tabular}


Table 1. Continuation.

\begin{tabular}{|c|c|c|c|c|c|c|c|c|c|}
\hline \multirow{2}{*}{$\begin{array}{l}\text { FAMILY } \\
\qquad \text { Species }^{*}\end{array}$} & \multirow[t]{2}{*}{ Habit } & \multirow[t]{2}{*}{ SC } & \multirow[t]{2}{*}{$\mathrm{DM}$} & \multicolumn{2}{|c|}{$\begin{array}{l}\text { Number of } \\
\text { seeds }\end{array}$} & \multicolumn{2}{|c|}{$\begin{array}{l}\text { Absolute } \\
\text { density }\end{array}$} & \multicolumn{2}{|c|}{$\begin{array}{l}\text { Absolute } \\
\text { frequency }\end{array}$} \\
\hline & & & & $\mathrm{BD}+$ & $\mathrm{BD}-$ & $\mathrm{BD}+$ & BD- & $\mathrm{BD}+$ & $\mathrm{BD}-$ \\
\hline \multicolumn{10}{|l|}{ BORAGINACEAE } \\
\hline Cordia sp. & TREE & - & $\mathrm{ZOO}$ & 2 & 97 & 0.27 & 12.93 & 0.07 & 0.37 \\
\hline \multicolumn{10}{|l|}{ ELAEOCARPACEAE } \\
\hline Sloanea guianensis (Aubl.) Benth. & TREE & NP & $\mathrm{ZOO}$ & - & 4 & - & 0.53 & - & 0.03 \\
\hline \multicolumn{10}{|l|}{ EUPHORBIACEAE } \\
\hline Alchornea sidifolia Müll.Arg. & TREE & $\mathrm{P}$ & ZOO & 285 & - & 38.00 & - & 0.20 & - \\
\hline Alchornea triplinervia (Spreng.) Müll.Arg. & TREE & $\mathrm{P}$ & ZOO & 51 & 10 & 6.80 & 1.33 & 0.17 & 0.23 \\
\hline Alchornea sp. & TREE & $\mathrm{P}$ & $\mathrm{ZOO}$ & 15 & 1 & 2.00 & 0.13 & 0.10 & 0.03 \\
\hline \multicolumn{10}{|l|}{ FABACEAE } \\
\hline Sclerolobium denudatum Vogel & TREE & NP & AUT & 1 & - & 0.13 & - & 0.03 & - \\
\hline Piptadenia gonoacantha (Mart.) J. F. Macbr. & TREE & $\mathrm{P}$ & AUT & - & 7 & - & 0.93 & - & 0.07 \\
\hline Fabaceae sp. & - & - & - & 2 & 4 & 0.27 & 0.53 & 0.03 & 0.13 \\
\hline \multicolumn{10}{|l|}{ LAURACEAE } \\
\hline Lauraceae sp. & TREE & - & $\mathrm{ZOO}$ & 8 & 23 & 1.07 & 3.07 & 0.07 & 0.27 \\
\hline \multicolumn{10}{|l|}{ MALPIGHIACEAE } \\
\hline Banisteriopsis sp. & - & - & ANE & 31 & - & 4.13 & - & 0.07 & - \\
\hline Heteropteris sp. & - & - & ANE & - & 2 & - & 0.27 & - & 0.03 \\
\hline Mascagnia sp. & - & - & ANE & - & 1 & - & 0.13 & - & 0.03 \\
\hline \multicolumn{10}{|l|}{ MELIACEAE } \\
\hline Cabralea canjerana (Vell.) Mart. & TREE & $\mathrm{P}$ & $\mathrm{ZOO}$ & 4 & 11 & 0.53 & 1.47 & 0.03 & 0.17 \\
\hline \multicolumn{10}{|l|}{ MENISPERMACEAE } \\
\hline Abuta selloana Eichler & SCAN & - & ZOO & - & 5 & - & 0.67 & - & 0.13 \\
\hline \multicolumn{10}{|l|}{ MYRSINACEAE } \\
\hline Ardisia sp. & TREE & - & ZOO & 540 & - & 72.00 & - & 0.17 & - \\
\hline Myrsinaceae sp. & TREE & - & $\mathrm{ZOO}$ & 259 & 5 & 34.53 & 0.67 & 0.30 & 0.17 \\
\hline Rapanea sp. & TREE & $\mathrm{P}$ & $\mathrm{ZOO}$ & 5 & 5 & 0.67 & 0.67 & 0.17 & 0.10 \\
\hline \multicolumn{10}{|l|}{ MYRTACEAE } \\
\hline Eugenia sp. & TREE & NP & $\mathrm{ZOO}$ & - & 5 & - & 0.67 & - & 0.07 \\
\hline Gomidesia sp. & TREE & NP & $\mathrm{ZOO}$ & 1 & 11 & 0.13 & 1.47 & 0.03 & 0.03 \\
\hline Myrcia sp. & TREE & NP & $\mathrm{ZOO}$ & 4 & 34 & 0.53 & 4.53 & 0.10 & 0.23 \\
\hline Psidium cattleianum Sabine & TREE & NP & ZOO & 81 & 4 & 10.80 & 0.53 & 0.13 & 0.10 \\
\hline \multicolumn{10}{|l|}{ PERACEAE } \\
\hline Pera glabrata (Schott) Poepp. ex Baill. & TREE & $\mathrm{P}$ & ZOO & 45 & 32 & 6.00 & 4.27 & 0.37 & 0.20 \\
\hline \multicolumn{10}{|l|}{ PHYTOLACCACEAE } \\
\hline Seguieria langsdorffii Moq. & TREE & $\mathrm{P}$ & $\mathrm{ZOO}$ & 14 & - & 1.87 & - & 0.03 & - \\
\hline \multicolumn{10}{|l|}{ RHAMNACEAE } \\
\hline Hovenia dulcis Thunb. & TREE & - & $\mathrm{ZOO}$ & 11 & - & 1.47 & - & 0.10 & - \\
\hline ROSACEAE & & & & & & & & & \\
\hline Prunus myrtifolia (L.) Urb. & TREE & NP & $\mathrm{ZOO}$ & 92 & 98 & 12.27 & 13.07 & 0.43 & 0.30 \\
\hline RUBIACEAE & & & & & & & & & \\
\hline Psychotria sessilis Vell. & SHR & NP & ZOO & 183 & - & 24.40 & - & 0.23 & - \\
\hline SAPINDACEAE & & & & & & & & & \\
\hline Cupania emarginata Cambess. & TREE & $\mathrm{P}$ & $\mathrm{ZOO}$ & 232 & - & 30.93 & - & 0.03 & - \\
\hline Cupania oblongifolia Mart. & TREE & $\mathrm{P}$ & $\mathrm{ZOO}$ & 30 & 85 & 4.00 & 11.33 & 0.33 & 0.40 \\
\hline Paullinia cf. coriacea Casar. & SCAN & - & ANE & 3 & - & 0.40 & - & 0.03 & - \\
\hline Paullinia cf. seminuda Radlk. & SCAN & - & ANE & - & 16 & - & 2.13 & - & 0.13 \\
\hline Serjania sp. & SCAN & - & ANE & - & 191 & - & 25.47 & - & 0.47 \\
\hline
\end{tabular}


Table 1. Continuation.

\begin{tabular}{|c|c|c|c|c|c|c|c|c|c|}
\hline \multirow{2}{*}{$\begin{array}{l}\text { FAMILY } \\
\text { Species* }\end{array}$} & \multirow[t]{2}{*}{ Habit } & \multirow[t]{2}{*}{ SC } & \multirow[t]{2}{*}{$\mathrm{DM}$} & \multicolumn{2}{|c|}{$\begin{array}{c}\text { Number of } \\
\text { seeds }\end{array}$} & \multicolumn{2}{|c|}{$\begin{array}{c}\text { Absolute } \\
\text { density }\end{array}$} & \multicolumn{2}{|c|}{$\begin{array}{l}\text { Absolute } \\
\text { frequency }\end{array}$} \\
\hline & & & & $\mathrm{BD}+$ & BD- & $\mathrm{BD}+$ & BD- & $\mathrm{BD}+$ & BD- \\
\hline \multicolumn{10}{|l|}{ SAPOTACEAE } \\
\hline Pouteria sp. & TREE & NP & $\mathrm{ZOO}$ & - & 1 & - & 0.13 & - & 0.03 \\
\hline \multicolumn{10}{|l|}{ SOLANACEAE } \\
\hline Solanaceae sp. & - & - & $\mathrm{ZOO}$ & 6 & 5 & 0.80 & 0.67 & 0.07 & 0.13 \\
\hline Solanum pseudoquina A. St. Hill & TREE & $\mathrm{P}$ & $\mathrm{ZOO}$ & 10 & 9 & 1.33 & 1.20 & 0.10 & 0.03 \\
\hline \multicolumn{10}{|l|}{ URTICACEAE } \\
\hline Cecropia glaziovii Snethl. & TREE & $\mathrm{P}$ & $\mathrm{ZOO}$ & 152 & 1 & 20.27 & 0.13 & 0.17 & 0.07 \\
\hline
\end{tabular}
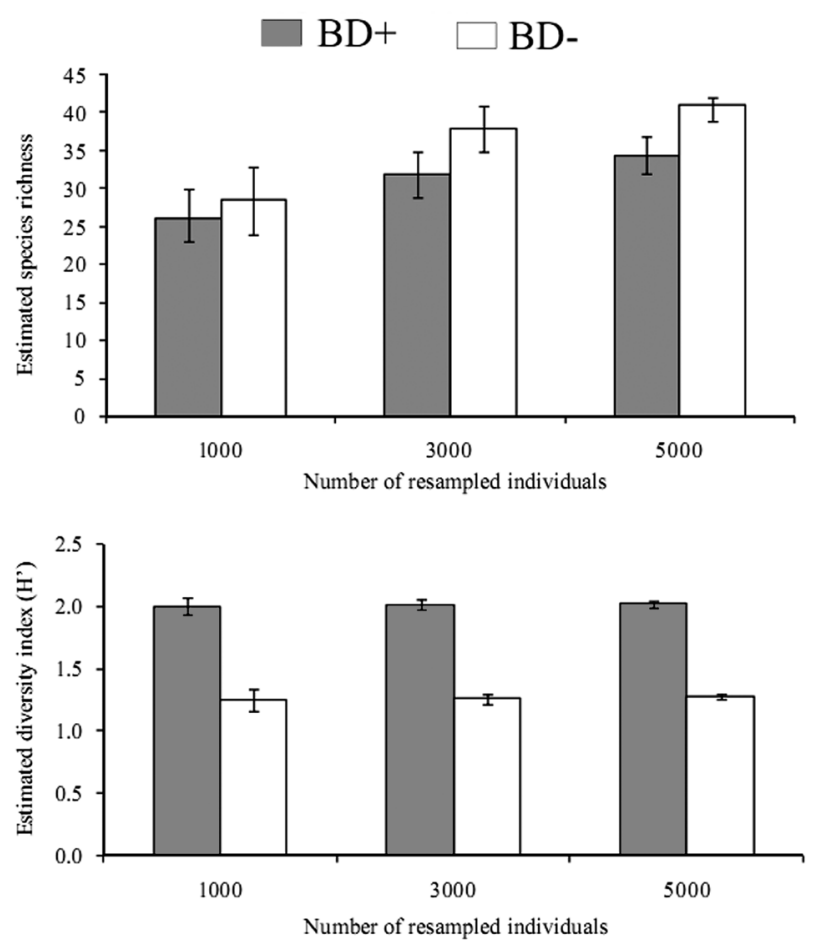

Figure 1. Estimated species richness and Shannon diversity index $\left(H^{\prime}\right)$ for all species sampled from the seed rain seed traps during the period from January to December 2007 in the areas containing bamboo $(\mathrm{BD}+)$ and the areas without bamboo (BD-) in the Fontes do Ipiranga State Park, São Paulo, Brazil. These estimates took into account the number of species that the two areas had in common at different resampling levels $(1000,3000$ and 5000) and the total number of tree species $(1000,2000$ and 3000) within each of the areas. The overlapping of confidence intervals revealed that there were no significant differences between areas.

\section{Functional groups}

We observed differences between functional groups in the two areas. In the $\mathrm{BD}-$ area, there was a greater abundance of diaspores from tree-shrub, pioneer and abiotic dispersal species. In contrast, the abundance of diaspores from lianas was greater in the $\mathrm{BD}+$ area. The only significant difference between the two areas in terms of the number of species from different functional groups present in the seed rain was for the abundance of tree-shrub species, which was greater in the $\mathrm{BD}+$ area. Chi-squared test results are shown in Tab. 2.

\section{Seed limitation}

For both of the areas sampled (BD+ and BD-), seed limitation was practically non-existent among the most abundant species, such as Mikania cordifolia and Asteraceae sp. 1 (0.13 for both), but was pronounced for Alchornea triplinervia $(>0.80)$, Piptocarpha oblonga $(0.90)$ and all other evaluated species (Tab. 3). None of the species evaluated in either area showed signs of source limitation, indicating that dispersal limitation was predominantly responsible for the seed limitation observed in the two areas. Of the seven species for which there was evidence of both dispersal and seed limitation, five were zoochorous and two were anemochorous.

\section{Discussion}

This study provided partial support for the hypothesis that the dominance of Aulonemia aristulata influenced the falling of diaspores for regeneration. Although seed density and species diversity were greater in the $\mathrm{BD}+$ area than in the $\mathrm{BD}-$ area, the association between bamboo dominance and the low density of trees was reflected in a lower richness of diaspores in the seed rain within the $\mathrm{BD}+$ area.

In relation to seed density, our findings did not corroborate those found by Abe et al. (2002) in a study carried out in Japan, Holz \& Veblen (2006) in the Andes, or Rother et al. (2009) in the Carlos Botelho State Park (PECB); each of these studies indicated that bamboo-dominated areas had lower seedfall rates. Furthermore, we found differences in species composition between areas with and without bamboo dominance within the same vegetation matrix, 
Table 2. Abundance and richness of diaspores collected in the seed rain from the Fontes do Ipiranga State Park, São Paulo, Brazil, from January to December 2007. Data are categorized by growth habit, success class and dispersal mode.

\begin{tabular}{|c|c|c|c|c|c|c|}
\hline \multirow{2}{*}{ Characteristic } & \multicolumn{3}{|c|}{ Abundance (\%) } & \multicolumn{3}{|c|}{ Richness (\%) } \\
\hline & $\mathrm{BD}+$ & $\mathrm{BD}-$ & Chi-square & $\mathrm{BD}+$ & BD- & Chi-square \\
\hline \multicolumn{7}{|l|}{ Habit } \\
\hline Tree-shrub & 41.1 & 79.8 & $\chi^{2}=31.3, \mathrm{df}=1, \mathrm{p}<0.001$ & 75.7 & 62.8 & $\chi^{2}=3.89, \mathrm{df}=1, \mathrm{p}<0.05$ \\
\hline Lianas & 32.8 & 8.4 & $\chi^{2}=18.4, \mathrm{df}=1, \mathrm{p}<0.001$ & 13.5 & 16.3 & $\chi^{2}=0.32, \mathrm{df}=1, \mathrm{n} . \mathrm{s}$ \\
\hline Undetermined & 26.1 & 11.8 & & 10.8 & 20.9 & \\
\hline \multicolumn{7}{|l|}{ Succession Class } \\
\hline Pioneers & 68.9 & 94.6 & $\chi^{2}=22.04, \mathrm{df}=1, \mathrm{p}<0.001$ & 53.6 & 48.1 & $\chi^{2}=0.59, \mathrm{df}=1$, n.s. \\
\hline Non-pioneers & 10.4 & 5.3 & $\chi^{2}=1.88, \mathrm{df}=1$, n.s. & 32.1 & 44.4 & $\chi^{2}=3.19, \mathrm{df}=1$, n.s. \\
\hline Undetermined & 20.6 & 0.10 & & 14.3 & 7.4 & \\
\hline \multicolumn{7}{|l|}{ Dispersal Mode } \\
\hline Abiotic & 78.6 & 91.5 & $\chi^{2}=6.75, \mathrm{df}=1, \mathrm{p}<0.05$ & 35.1 & 45.2 & $\chi^{2}=2.12, \mathrm{df}=1, \mathrm{n} . \mathrm{s}$ \\
\hline Biotic & 21.4 & 8.4 & $\chi^{2}=0.59, \mathrm{df}=1, \mathrm{n} . \mathrm{s}$ & 62.2 & 52.4 & $\chi^{2}=1.96, \mathrm{df}=1, \mathrm{n} . \mathrm{s}$ \\
\hline Undetermined & 0.02 & 0.06 & & 2.7 & 2.4 & \\
\hline
\end{tabular}

BD+ - bamboo dominance; BD- - no bamboo dominance; $\mathrm{df}$ - degrees of freedom; n.s. - not significant.

Table 3. Index values for seed limitation, source limitation and dispersal limitation for seeds from the most common and most abundant species in areas BD+ and BD- .

\begin{tabular}{|c|c|c|c|c|c|c|}
\hline \multirow{3}{*}{ Species } & \multicolumn{3}{|c|}{ Area with bamboo dominance } & \multicolumn{3}{|c|}{ Area without bamboo dominance } \\
\hline & \multicolumn{3}{|c|}{ Type of Limitation* } & \multicolumn{3}{|c|}{ Type of Limitation ${ }^{*}$} \\
\hline & Seeds & Source & Dispersal & Seeds & Source & Dispersal \\
\hline Alchornea triplinervia & 0.83 & 0.00 & 0.83 & 0.77 & 0.24 & 0.69 \\
\hline Asteraceae sp. 1 & 0.13 & 0.00 & 0.13 & 0.13 & 0.00 & 0.13 \\
\hline Cupania oblongifolia & 0.67 & 0.05 & 0.65 & 0.60 & 0.00 & 0.60 \\
\hline Mikania cordifolia & 0.13 & 0.00 & 0.13 & 0.73 & 0.00 & 0.73 \\
\hline Pera glabrata & 0.63 & 0.02 & 0.63 & 0.80 & 0.00 & 0.80 \\
\hline Piptocarpha oblonga & 0.60 & 0.00 & 0.60 & 0.90 & 0.00 & 0.90 \\
\hline Prunus myrtifolia & 0.57 & 0.01 & 0.56 & 0.70 & 0.00 & 0.70 \\
\hline Vernonia diffusa & 0.60 & 0.00 & 0.60 & 0.13 & 0.00 & 0.13 \\
\hline Xylopia brasiliensis & 0.63 & 0.05 & 0.61 & 0.73 & 0.00 & 0.73 \\
\hline
\end{tabular}

*Index values $>0.60$ suggest major limitation.

corroborating the findings of Rother et al. (2009). These differences in results can most likely be attributed to different sampling methods as well different forest successional stages and/or historic preservation of study areas. Nevertheless, our results showed that the seed rain was composed of a set of propagules that were able to recolonize the area after disturbances had occurred or after the death of bamboo.

In the PEFI, the higher abundance of seeds sampled in the $\mathrm{BD}+$ area (approximately six times greater than in the $\mathrm{BD}-$ area) was associated with the presence of liana species. The abundance and dominance of this group are associated with the level of disturbance and the age of the forest (Putz 1984; Senbeta et al. 2005; Madeira et al. 2009), which are higher in native forests with an intermediate stage of succession due to a structural and microclimatic conditions that favor an increase in density and biomass (Madeira et al. 2009); such conditions were present in our study area. The presence of liana and bamboo species within the study area may modify the forest structure and composition, thus inhibiting the germination of tree seeds and seedling growth and modifying processes related to forest regeneration and succession (Campanello et al. 2007).

Among the tree-shrub species sampled in the seed rain, we found that pioneer species were more abundant than non-pioneer species in both areas, although the number of seeds from pioneer species was greater in the BD- area. Similarly, Rother et al. (2009) noted the high abundance of a pioneer species in the seed rain. According to the authors, pioneer species can benefit from the death of bamboo plants, rapidly colonizing open areas previously occupied by 
bamboo. Previous studies have shown that pioneer species are predominantly dispersed by animals (primarily birds) that perch in canopy trees (Guevara \& Laborde 1993). The lower number of pioneer species seeds in the $\mathrm{BD}+$ area was associated with a discontinuous canopy and a low density of tree species.

The higher density of seeds in the $\mathrm{BD}+$ area was associated with higher species diversity and might be related to the high number of anemochorous species sampled in the seed rain. Studies in other semideciduous forests have shown that anemochory is the main seed dispersal mode (Grombone-Guaratini \& Rodrigues 2002; Barbosa \& Pizo 2006; Bertoncini \& Rodrigues 2008). The higher percent canopy opening, previously described for the studied area, is a facilitating factor for anemochorous dispersal (Penhalber \& Mantovani 1997; Vinha et al. 2011). However, the high number of anemochorous species differs from the findings of Rother et al. (2009) in a study of Montane Atlantic forest areas in which the number and density of seeds from zoochorous species was greater than from anemochorous species. The differences observed in the seed rain between the PEFI and the PECB are most likely due to the higher degree of isolation of the PEFI, as well as to different disturbance regimes, higher canopy densities in the PECB (favoring the presence of dispersing agents), and degree of bamboo dominance and the study length (i.e., the consideration of a full cycle of bamboo).

The small number of zoochorous species sampled in the seed rain may be the result of a reduction in the number of vertebrates acting as dispersing agents within the forest fragments. A reduction in seed-delivery services provided by vertebrates can modify the flow of diaspores and, consequently, alter the composition of the seed rain (Melo et al. 2006). Seed limitation of zoochorous species due to a limited number of dispersing agents in both of the sampled areas emphasizes the absence of seed dispersers within this urban forest fragment. Although there are numerous species of native fauna in the PEFI (Management Plan 2008), the study area was located within the city of São Paulo and was isolated from other forested areas, resulting in a low faunal richness. Therefore, it is likely that there are fewer zoochorous species than anemochorous species (Janzen \& Vázquez-Yanes 1991). The absence of dispersing agents could have a negative effect on the zoochorous dispersal of seeds by indirectly changing the floristic composition and diversity of vegetation as well as by favoring the establishment of species utilizing abiotic dispersal due to a lack of competition between these groups (Tabarelli et al. 1999, Wright et al. 2000). Despite being highly abundant in the seed rain and not requiring biotic agents for dispersal purposes, two anemochorous species (P. oblonga and V. diffusa) were shown to have seed limitation; this result could be attributed to an inability to reach productive maturity during the evaluated period (Barbosa \& Pizo 2006). However, seed limitation was similar for both areas, indicating that the abundance and density of bamboo did not directly affect the seed rain. Therefore, recruitment limitation (Muller-Landau et al. 2002) might be the phase that most influences community dynamics and makes it possible to maintain a degraded state due to the self-perpetuating cycle of the bamboo. Recruitment limitation affects young individuals and may have a significant effect on the regeneration of tropical forests (Gillman et al. 2004).

In view of the wide availability of tree-shrub species found in the seed rain in the $\mathrm{BD}+$ area, our findings suggest that the dominance of bamboo and maintenance of a degraded state cannot be attributed to the flow of diaspores to the study area. In addition, Vinha et al. (2011), in a study of the same area, demonstrated that the soil seed bank has a stock of native seed species sufficient to recolonize the entire area.

The results obtained by Vinha et al. (2011) and those from the present study demonstrate that past disturbances (i.e., partial deforestation, atmospheric pollution and edge effects) affected the area by increasing the number of clearings, reducing the number of trees and increasing the availability of light, thereby facilitating the dominance of bamboo. However, despite the disturbance caused by bamboos in the study area, we concluded that seed rain was not the limiting phase of the regeneration process. Although the management of bamboo-dominated areas has been identified as an important forest restoration method (Larpkern et al. 2011), studies that fully evaluate other phases of forest dynamics should be carried out so that other appropriate management strategies can be considered.

\section{Acknowledgments}

The authors thank Lynn G. Clark and Pedro L. Viana for their assistance in the identification of bamboo species as well as the interns and other collaborators who assisted in the collection and sorting of the botanical material, especially Valdo da França Santos and Ewerton Caltran Manarin. We are also grateful to the two anonymous reviewers whose contributions improved the quality of this manuscript considerably. This study received financial support from the Fundação de Amparo à Pesquisa do Estado de São Paulo (FAPESP, São Paulo State Research Foundation; grant no. 05/51747-2): to the first Author.

\section{References}

Abe M; Izaki J.; Masaki T.; Makita A. \& Nakashizuka T. 2002. The effects of Sasa and canopy gap formation on tree regeneration in an old beech forest. Journal of Vegetation Science 13: 565-574.

APG II 2003. An update of the Angiosperm Phylogeny Group classification for the orders and families of flowering plants: APG II. Botanical Journal of Linnean Society 141: 399-436.

Barbosa, K.C. \& Pizo, M.A. 2006. Seed rain and seed limitation in a planted gallery forest in Brazil. Restoration Ecology 4: 504-515. 
Barros, F.; Mamede, M.C.H.; Melo, M.M.R.F.; Lopes, E.; Jung-Mendaçolli, S.; Kirizawa, M.; Muniz, C.F.S.; Makino-Watanabe, H.; Chiea, S.A.C. \& Melhem, T.S. 2002. A Flora Fanerogâmica do PEFI: composição, afinidades e conservação. Pp. 93-110. In: Bicudo, D.C.; Forti, M.C. \& Bicudo C.E.M. (Eds.). Parque Estadual das Fontes do Ipiranga: uma reserva Biológica na cidade de São Paulo, São Paulo. Secretaria do Meio Ambiente do Estado de São Paulo, São Paulo.

Bertoncini, A.P. \& Rodrigues, R.R. 2008. Forest restoration in an indigenous land considering a forest remnant influence (Avaí, São Paulo State, Brazil). Forest Ecology and Management 255: 513-521.

Burley, S.; Robinson, S.L.; Lundholm, J.T. 2008. Post-hurricane vegetation recovery in an urban forest. Landscape and Urban Planning 85: $111-122$

Campanello, P.I.; Gatti, M.G.; Ares, A.; Montti, L. \& Goldstein, G. 2007. Tree regeneration and microclimate in a liana and bamboo-dominated semideciduous Atlantic Forest. Forest Ecology and Management 252: 108-117.

Carvalho, P.E.R. 1994. Espécies florestais brasileiras: recomendações silviculturais, potencialidades e uso da madeira. Embrapa-CNPF/ SPI, Curitiba.

Chant, T.D.; Gallego, A.H.; Saornil, J.V. \& Keely, M. 2010. Urban influence on changes in linear forest edge structure. Landscape and Urban Planning 96: 12-18.

Clark, J.S.; Macklin, E. \& Wood, L. 1998. Stages and spatial scales of recruitment limitation in southern Appalachian Forests. Ecological Monographs 68: 213-235.

Doležal, J.; Matsuki, S. \& Hara, T. 2009. Effects of dwarf-bamboo understory on tree seedling emergence and survival in a mixed-oak forest in northen Japan: a multi-site experimental study. Community Ecology 10: $225-235$.

Foster, R.B. 1985. The seasonal rhythm of fruitfall on Barro Colorado Island. Pp: 151-172 In: Leigh, E.G. \& Windsor, D.M. (Eds.). The ecology of a tropical forest. Seasonal rhythms and long-term changes. Smithsonian Institution Press. Washington, DC.

Gandolfi, S.; Leitão Filho, H.F. \& Bezerra, C.L. 1995. Levantamento florístico e caráter sucessional das espécies arbustivo-arbóreas de uma floresta mesófila semidecídua no Município de Guarulhos, SP. Revista Brasileira de Biologia 55: 753-767.

Gillman, L.N., Ogden, J., Wright, S.D., Stewart, K.L. \& Walsh. D.P. 2004. The influence of macro-litterfall and forest structure on litterfall damage to seedlings. Austral Ecology 29: 305-312.

González, M.E.; Veblen, T.T.; Donoso, C. \& Valeria, L. 2002. Tree regeneration responses in a lowland Nothofagus-dominated forest after bamboo dieback in South-Central Chile. Plant Ecology 161: 59-73.

Gotelli, N.J. \& Entsminger, G.L. 2001. EcoSim: Null models software for ecology. Version 7.0. Acquired Intelligence Inc. \& Kesey-Bear.

Gotelli, N.J. \& Colwell, R.K., 2001. Quantifying biodiversity: procedures and pitfalls in the measurement and comparison of species richness. Ecology Letters 4: 379-391.

Griscom, B.W. \& Ashton, P.M.S. 2003. Bamboo control of forest succession: Guadua sarcocarpa in Southeastern Peru. Forest Ecology and Management 175: 445-454.

Griscom, B.W. \& Ashton, P.M.S. 2006. A self-perpetuating bamboo disturbance cycle in a Neotropical forest. Journal of Tropical Ecology 22: $587-597$

Grombone-Guaratini, M.T. \& Rodrigues, R.R. 2002. Seed bank and seed rain in a seasonal semi-deciduous Forest in south-eastern Brazil. Journal Tropical Ecology 18: 759-774.

Grombone-Guaratini, M.T.; Jessen, R.C.; Cardoso-Lopes, E.M.; Torres, L.M.B. 2009. Allelopathic potential of Aulonemia aristulata (Doll) MacClure, a native bamboo of Atlantic Rain Forest. Allelopathy Journal 24: 183-190.

Grombone- Guaratini, M.T.; Nascimento, A.; Santos-Gonçalves, A.P. 2011. Flowering and fruiting of Aulonemia aristulata: a gynomonoecious woody bamboo species from Atlantic forest in Brazil. Revista Brasileira de Botânica 34: 135-140.

Guevara S. \& Laborde J. 1993. Monitoring seed dispersal at isolated standing trees in tropical pastures: consequences for local species availability. Vegetatio: Acta Geobotanica 107/108: 319-338.
Guilherme, F.A.G.; Oliveira-Filho, A.T.; Appolinário, V. \& Bearzoti, E. 2004. Effects of flooding regime and woody bamboos on tree community dynamics in a section of tropical semi-deciduous forest in South-Eastern Brazil. Plant Ecology 174: 19-36.

Hammer, Ø.; Harper, D.A.T. \& Ryan, P.D. 2001. PAST: Paleontological Statistics Software Package for Education and Data Analysis. Palaeontologia Electronica 4: 1-9.

Harper, J.L. 1977. Population Biology of Plants. London, Academic Press.

Holl, K. 1999. Factors limiting tropical rain forest regeneration in abandoned pasture: seed rain, seed germination, microclimate, and soil. Biotropica 31: 229-242.

Holz, C.A. \& Veblen, T.T. 2006. Tree regeneration responses to Chusquea montana bamboo die-off in a subalpine Nothofagus forest in the southern Andes. Journal of Vegetation Science 17: 19-28.

Janzen, D.H. 1976. Why bamboos wait so long to flower. Annual Review of Ecology and Systematic 7: 347-391.

Janzen, C.D. \& Vázquez_Yanes, C. 1991. Aspects of tropical seed ecology of relevance to management of tropical forested wildlands. Pp. 137-157. In: Gómez-Pompa, A.; Whitmore, T.C. \& Hadley, M. Rain forest regeneration and management. United Nacions Educational, Scientific and Cultural Paris, Organization and The Parthenon Publishing Group.

Judziewicz, E.J.; Clarck, L.G.; Londoño, X. \& Stern, M.J. 1999. American bamboos. Washington, Smithsonian Institute Press.

Köppen, W. 1948. Climatologia. Editora Fondo de Cultura Económica, México.

Larpkern P.; Moe S.R. \& Totland O. 2011. Bamboo dominance reduces tree regeneration in a disturbed tropical forest. Oecologia 165: 161-168.

Laurance, W.F.; Pérez-Salicrup, D.; Delamônica, P.; Fearnside, P.; D'Angelo, S.; Jerozolinski, A.; Pohl, L. \& Lovejoy, T.E. 2001. Rain forest fragmentation and the structure of Amazonian liana communities. Ecology 82: $105-116$

Lorenzi, H. 1992. Árvores brasileiras. v. I, II. Nova Odessa, Plantarum Editora.

Lorenzi, H. 1998. Árvores brasileiras. v. III. Nova Odessa, Plantarum Editora.

McCune, B., Mefford, M.J. 2011. PC-ORD Multivariate analysis of ecological data, Version 6.00. MjM Software Design, Oregon, Gleneden Beach.

Madeira, B.G.; Santo, M.M.E.; Neto, S.A.; Nunes, Y.R.F.; Azofeifa, G.A.S.; Fernandes, G.W. \& Quesada, M. 2009. Changes in tree and liana communities along a successional gradient in a tropical dry forest in south-eastern Brazil. Plant Ecololgy 201: 291-304.

Melo, F.P.L.; Dirzo, R. \& Tabarelli, M. 2006. Biased seed rain in forest edges: evidence from the Brazilian Atlantic forest. Biological Conservation 132: $50-60$.

Müeller-Dombois, D. \& Ellenberg, H. 1974. Aims and Methods of Vegetation Ecology. New York, John Wiley.

Muller-Landau, H.C.; Wright, S.J.; Calderón, O.; Hubbell, S.P. \& Foster, R.B. 2002. Assessing recruitment limitation: concepts, methods and case studies from a Tropical Forest. Pp. 35- 53. In: Levey, D.J.; Silva, W.R.; Galetti, M. (Eds.). Seed dispersal and frugivory: ecology, evolution and conservation. Wallingford, CABI Publishing.

Narukawa, Y. \& Yamamoto, S. 2002. Effects of dwarf bamboo (Sasa sp.) and forest floor microsites on conifer seedling recruitment in a subalpine forest, Japan. Forest Ecology and Management 163: 61-70.

Oliveira-Filho, A.T. \& Fontes, M.A. 2000. Patterns of floristic differentiation among Atlantic forests in southeastern Brazil and the influence of climate. Biotropica 32: 793-810

Penhalber, E.F. \& Mantovani, W. 1997. Floração e chuva de sementes em mata secundária em São Paulo, SP. Revista Brasileira de Botânica 20: $205-220$.

Pivello, V.R. \& Peccinini, A.A. 2002. A vegetação do PEFI. Pp. 75-92. In: Bicudo, D.C.; Forti, M.C. \& Bicudo C.E.M. (Eds.). Parque Estadual das Fontes do Ipiranga: uma reserva Biológica na cidade de São Paulo, São Paulo. Secretaria do Meio Ambiente do Estado de São Paulo, São Paulo.

Pivello, V.R.; Petenon, D., Jesus, F.M.; Meirelles, S.T.; Vidal, M.M.; Alonso, R.A.S., Franco, G.A.D.C. \& Metzer, J.P. 2006. Chuva de sementes em fragmentos de floresta Atlântica (São Paulo, SP, Brazil), sob diferentes situações de conectividade, estrutura florestal e proximidade da borda. Acta Botanica Brasilica 20: 845-829.

Plano de manejo do Parque Estadual das Fontes do Ipiranga. 2008. 32p. 
Putz, F.E. 1984. The natural history of lianas on Barro Colorado Island, Panama. Ecology 65: 1713-1724.

Rossi, L. 1994. A flora arbórea-arbustiva da Mata da Reserva da Cidade Universitária "Armando Salles de Oliveira" (São Paulo, Brasil). Boletim do Instituto de Botânica 9: 1-105.

Rother, D.; Rodrigues, R.R. \& Pizo, M. A. 2009. Effects of bamboo stands on seed rain and seed limitation in a rainforest. Forest Ecology and Management 257: 885-892.

Senbeta, F.; Schmitt, C.; Denich, M.; Demissew, S.; Vlek, P.I.G.; Preisinger, H.; Woldemariam, T. \& Teketay, D. 2005. The diversity and distribution of lianas in the Afromontane rain forests of Ethiopia. Diversity and Distribution 11: 443-452.

Söderstrom, T.R. \& Calderon, C.E. 1979. Ecology and phytosociology of bamboo vegetation: 1. Distribution and environment of the Bambusoideae. Pp. 224-236. In: Numata, M. (Ed.). Ecology of grasslands and bamboolands in the world. Jena, Gustav Fischer Verlag.

Swaine, M.D. \& Whitmore, T.C. 1988. On the definition of ecological species groups in tropical rain forest. Vegetatio 75: 81-86.

Tabarelli M., Mantovani, W. \& Peres C.A. 1999. Effects of habitat fragmentation on plant guild structure in the montane Atlantic forest of southeastern Brazil. Biological Conservation 91: 119-127. van der Pijl, L. 1982. Principles of dispersal in higher plants. New York, Springer-Verlag.

Veloso, P.H., Rangel-Filho, A.L.R. \& Lima, J.C.A. 1991. Classificação da vegetação brasileira adaptada a um sistema universal. IBGE, Rio de Janeiro.

Vinha, D.; Alves, L.F.; Zaidan, L.B.P. \& Grombone-Guaratini, M.T. 2011. The potential of the soil seed bank for the regeneration of a tropical urban forest dominated by bamboo. Landscape and Urban Planning 99: 178-185.

Wanderley, M.G.L., Shepherd, G.J. \& Giulietti A.M. 2002. Flora fanerogâmica de Estado de São Paulo. v. 2. São Paulo, Ed. HUCITECH.

Widmer, Y.1998. Pattern and performance of understory bamboos (Chusquea spp.) under different canopy closures in old-growth oak forest in Costa Rica. Biotropica 30: 400-415.

Wright, S.J.; Zeballo, H.; Domínguez, I.; Gallardo, M.M.; Moreno, M.C. \& Ibánez, R. 2002. Poachers alter mammal abundance, seed dispersal, and seed predation in a neotropical forest. Conservation Biology 14: $227-239$.

Zar, J.H. 1999. Biostatistical analysis. Prentice Hall, Upper Saddle River, New Jersey. 